\title{
Endophytic bacterial community composition in wheat (Triticum aestivum) is determined by plant tissue type, developmental stage and soil nutrient availability
}

Article

Accepted Version

Robinson, R. J., Fraaije, B. A., Clark, I. M., Jackson, R., Hirsch, P. R. and Mauchline, T. H. (2016) Endophytic bacterial community composition in wheat (Triticum aestivum) is determined by plant tissue type, developmental stage and soil nutrient availability. Plant and Soil, 405 (1-2). pp. 381-396. ISSN 0032-079X doi: https://doi.org/10.1007/s11104-0152495-4 (The final publication is available at link.springer.com) Available at https://centaur.reading.ac.uk/40199/

It is advisable to refer to the publisher's version if you intend to cite from the work. See Guidance on citing.

To link to this article DOI: http://dx.doi.org/10.1007/s11104-015-2495-4

Publisher: Springer

All outputs in CentAUR are protected by Intellectual Property Rights law, including copyright law. Copyright and IPR is retained by the creators or other copyright holders. Terms and conditions for use of this material are defined in 
the End User Agreement.

www.reading.ac.uk/centaur

\section{CentAUR}

Central Archive at the University of Reading

Reading's research outputs online 
Endophytic bacterial community composition in wheat (Triticum aestivum) is determined by plant tissue type, developmental stage and soil nutrient availability

Authors:

Rebekah J Robinson ${ }^{1}$, Bart A Fraaije ${ }^{1}$, Ian M Clark ${ }^{1}$, Robert W Jackson ${ }^{2}$, Penny R Hirsch ${ }^{1}$, Tim H Mauchline $^{1}$

${ }^{1}$ Rothamsted Research, West Common, Harpenden, UK, AL5 2JQ

${ }^{2}$ School of Biological Sciences, University of Reading, Whiteknights, UK, RG6 6AH

Corresponding Author:

Tim Mauchline, Department of AgroEcology, Rothamsted Research, West Common, Harpenden, AL5 2JQ

Tel: 01582763133

Email: tim.mauchline@ rothamsted.ac.uk

Keywords: bacterial endophyte, community structure, culture dependent, fertiliser, RFLP, nitrogen. 


\begin{abstract}
Aims: To understand effects of tissue type, growth stage and soil fertilisers on bacterial endophyte communities of winter wheat (Triticum aestivum cv. Hereward).

Methods: Endophytes were isolated from wheat grown under six fertiliser conditions in the long term Broadbalk Experiment at Rothamsted Research, UK. Samples were taken in May and July from root and leaf tissues.
\end{abstract}

Results: Root and leaf communities differed in abundance and composition of endophytes.

Endophytes were most abundant in roots and the Proteobacteria were most prevalent. In contrast, Firmicutes and Actinobacteria, the Gram positive phyla, were most prevalent in the leaves. Both fertiliser treatment and sample time influenced abundance and relative proportions of each phylum and genus in the endosphere. A higher density of endophytes was found in the Nil input treatment plants.

Conclusions: Robust isolation techniques and stringent controls are critical for accurate recovery of endophytes. The plant tissue type, plant growth stage, and soil fertiliser treatment all contribute to the composition of the endophytic bacterial community in wheat. These results should help facilitate targeted development of endophytes for beneficial applications in agriculture. 


\section{Introduction}

Wheat is an important crop worldwide and the Food and Agricultural Organisation of the United Nations predicts an increased demand to 746 million tonnes by 2020,11\% above the annual production recorded during $2008-2010$ (OECD/FAO 2011). This increase in production needs to be achieved despite the growing number of challenges to modern agriculture including restrictions in the use of pesticides (Barroso 2011), concerns about the availability and environmental impact of fertiliser inputs (Rees et al. 2013; van Grinsven et al. 2013), and the potential negative impacts of climate change on wheat yields and disease spectrum (Olesen et al. 2011). The beneficial traits provided by endophytes may offer a solution for improving wheat yields in a sustainable manner.

Endophytic bacteria have a particularly close association with plants, existing for at least part of their life cycle in living plant tissue without inducing symptoms of disease (Hardoim et al. 2008; Wilson 1995). When endophytes have been studied they have often been shown to promote plant growth through a number of mechanisms including; phytostimulation, through production of indole acetic acid or synthesis of the enzyme 1-aminocyclopropane-1-carboxylic acid deaminase (de Santi Ferrara et al. 2012; Glick et al. 2007); biofertilisation, through solubilisation of minerals (Gupta et al. 2012; Lopez et al. 2012) or bacterial nitrogen fixation (Thaweenut et al. 2010); and pathogen control, through priming of the plant defence system (Monteiro et al. 2012; Pavlo et al. 2011; Pineda et al. 2012) or production of antimicrobial metabolites (Ramesh et al. 2009; Ren et al. 2013). To effectively utilise these beneficial traits in vivo, it is imperative that the determinants of endophyte community structure, colonisation and establishment are fully understood.

The Broadbalk field site at Rothamsted Research provides a unique opportunity to study and compare wheat associated microbial communities under long term fertiliser treatments. The Broadbalk field experiment was initiated in 1843 to study the influence of fertiliser treatments on the growth and yields of winter wheat (Triticum aestivum). Plots receive farm yard manure (FYM) or inorganic nitrogen applications at levels of 0 to $288 \mathrm{~kg} \mathrm{~N} \mathrm{ha}^{-1} \mathrm{yr}^{-1}$ with additional application of phosphate (P), potassium $(\mathrm{K})$ and magnesium $(\mathrm{Mg})$. Treatments have remained broadly unchanged through the history of the experiment, although agronomic adjustments such as the introduction of mechanised ploughing and deployment of short straw cultivars and pesticides have been made to reflect changes in modern agricultural practices (Rothamsted 2006).

Three possible determinants of endophyte communities within wheat plants are tissue type, growth stage and fertiliser inputs. Understanding the contributions of these determinants should guide 
application of endophytes in agriculture. For example, leaf associated endophyte might be targeted for use in bio-control of foliar pathogens. It is important to understand the contribution of growth stage to determine whether endophytes applied at the start of the season are likely to persist through the season. We hypothesise that long term soil fertiliser treatments will result in differences in the endophyte communities between treatments. The long term nature of the Broadbalk experiment used here means any adaptation of endophytes to fertiliser treatments should be detectable. For example, in the low nitrogen input treatment plots there may be a higher abundance of bacteria capable of nitrogen fixation. Alternatively, the endophyte population might be determined solely by the plant genotype and we might see a conserved endophyte population in all plants across the fertiliser treatments.

A number of limitations for culture independent work guided our choice of a culture dependent approach in this study. Many culture independent studies use a cultured sterility control for molecular isolation without confirming that the DNA of the non-viable cells has been degraded by the sterilisation method. This limitation was discussed by Chelius and Triplett (2001) following the design of their now commonly used primers, 799f and 1492r, to exclude chloroplast 16S rRNA genes. Removal of the surface tissue by sonication goes some way towards addressing this problem (as used effectively by Bulgarelli et al., (2012)and Lundberg et al., (2012)) but appropriate molecular controls have still not been fully developed. Poor controls for culture independent studies mean that rhizospheric or saprophytic bacteria are likely being included in many studies as putative endophytic species. Primers used in culture independent studies also have biases for recovery of the bacterial population (Klindworth et al. 2013). The 16S rRNA gene has become the standard gene for identification of bacteria, largely due to the availability of wide coverage databases such as the Ribosomal Database Project. However, variable copy number of the 16S rRNA gene creates biases in culture independent abundance and diversity studies (Kembel et al. 2012). Copy numbers of the $16 \mathrm{~S}$ rRNA gene can vary from 1 to 15 copies and unless this variation is normalised the numbers of sequencing reads from culture independent studies will not be representative of the number of endophytic bacterial cells.

Culture studies will inevitably miss a number of the rarer and difficult to culture species in the community. However is has been observed that most bacteria associated with plants through molecular methods are closely related to culturable species (Bodenhausen et al. 2013). It is also likely that due to the growth conditions and availability of nutrients within the plant, endophytes are likely to be better adapted to laboratory culture conditions than are general soil bacteria. Use of a culture dependent method also provides isolates for further detailed study of colonisation and plant beneficial traits. 
In this study we first established a rigorous method for isolation of endophytic bacteria from wheat plants. We then sampled the culturable endophytic community of winter wheat plants (Triticum aestivum cv. Hereward) in six treatment plots of the Broadbalk experiment. These data were analysed for abundance and relative proportion at the phylum and genus level to determine the influences of tissue type, growth stage, and fertiliser treatment on the endophytic bacterial community of winter wheat. 


\section{Materials and methods}

\section{Site description and sampling of wheat plants}

Broadbalk soil is a flinty, silty, clay loam of the Batcombe series (Chromic Luvisol - FAO classification). The site is freely draining with a slope of $1^{\circ}$, west to east (Watts et al. 2006). Soil organic carbon content varies between $0.7-3.2 \%$ and clay content varies between $19-39 \%$ according to the treatment history of the plot. Farmyard manure (FYM) treatments have significantly higher organic carbon and moisture content than plots treated with inorganic fertiliser or with no fertiliser input (Clark et al. 2012). The cultivated experimental area of the Broadbalk field site is approximately $150 \mathrm{~m}$ by $320 \mathrm{~m}$. The field is divided longitudinally into fertiliser treatment strips $5 \mathrm{~m}$ wide and transverse sections $23 \mathrm{~m}$ long according to agricultural practices (Fig. 1). For the purpose of this study the treatment plots were further divided into three replicate sections $7 \mathrm{~m}$ by $5 \mathrm{~m}$ with $1 \mathrm{~m}$ discarded from each end of the plot. Plants of wheat cv. Hereward were sampled from Section 6, growing continuous-wheat and receiving no foliar fungicide applications. Plants receiving six different fertiliser treatments; two without $\mathrm{N}$, two with inorganic $\mathrm{N}$ and two with organic $\mathrm{N}$ as FYM (Table 1), were sampled on $11^{\text {th }}$ May 2011 and $16^{\text {th }}$ July 2011, corresponding to Zadoks growth stages GS 37 and GS 83 respectively.

At each sampling event four plants were carefully removed in a zigzag sampling pattern from each of the three replicate sections of the six fertiliser treatments. Surface loose soil was kept with the roots to limit the damage to the root system. Whole plants were transported in sealed polythene bags in cool boxes and stored at $4{ }^{\circ} \mathrm{C}$ for processing within the following four day period.

\section{Isolation of wheat endophytes}

Roots were carefully washed with tap water to remove surface adhering soil. Each plant was then sectioned into $5 \mathrm{~cm}$ nodal root sections and $5 \mathrm{~cm}$ leaf-lamina sections from the top three leaves (approximately $0.4 \mathrm{~g}$ FW tissue per sample). Samples were twice vortexed in sterile distilled water (SDW) before sterilisation using an optimised surface sterilisation procedure for field grown wheat plants: a 16 minute wash with agitation in sodium hypochlorite solution (1.6\% active chlorine), a rinse in SDW, a one minute wash in 95\% ethanol, followed by three rinses in SDW with agitation. The total final $50 \mathrm{~mL}$ rinse was retained and pelleted by centrifugation at $3000 \mathrm{x} \mathrm{g}$ for 15 minutes at $25{ }^{\circ} \mathrm{C}$ to allow plating of the entire rinse as a robust surface sterility control for each sample. Samples with more than 10 colonies on the control plate were discarded as a source of putative endophytes (equivalent to greater than $25 \mathrm{CFU} \mathrm{g}^{-1} \mathrm{FW}$ remaining on the sample surface). In May, colonies from 
34 of the 72 processed plants were included in further analysis; and in July, colonies from 30 of the 72 processed plants were included in further analysis (Table 2).

Following sterilisation, $1 \mathrm{~cm}$ from the end of each sample was removed to discard internal tissue in which the $\mathrm{NaClO}$ may have penetrated. Fresh tissue samples were weighed and $1 \mathrm{ml}$ SDW was added for every $0.1 \mathrm{~g}$ tissue. Samples were completely macerated in SDW using a sterile pestle and mortar, diluted a further hundredfold, $100 \mu \mathrm{l}$ plated onto a $1 / 10^{\text {th }}$ TSA plate and incubated for 6 days at $28{ }^{\circ} \mathrm{C}$. Plate counts were taken and a random segment of each plate containing $10-15$ colonies was selected and bacterial colonies were passed through three rounds of re-streaking to ensure isolation of single colonies of pure culture before long term storage in $15 \%$ glycerol at $-80{ }^{\circ} \mathrm{C}$.

\section{PCR amplification of 16S rRNA genes}

PCR was performed with the bacterial primers MF (5'-CCTACGGGAGGCAGCAG) (Muyzer et al. 1993) and 1389r (5' -ACGGGCGGTGTGTACAA) (Marchesi et al. 1998; Osborn et al. 2000), which amplify variable regions V3 to V8 of the 16S rRNA gene in most bacteria. Primers were chosen on the basis of their high coverage of 16S rRNA genes in the Ribosomal Database Project database (Cole et al. 2009). PCR amplification was carried out in $25 \mu 1$ reaction volumes containing the following reagents: 1 x Bioline PCR buffer, $2 \mathrm{mM} \mathrm{MgCl} 2,1 \mu \mathrm{M}$ each primer, $200 \mu \mathrm{M}$ each deoxynucleoside triphosphate, $1.25 \mathrm{U}$ Bioline Taq polymerase, and $1 \mu \mathrm{l}$ of cell lysate. Cell lysate was created by suspending a bacterial colony in $200 \mu \mathrm{l} \mathrm{SDW}$ and heating to $95^{\circ} \mathrm{C}$ for 5 minutes. Amplification conditions were as follows: 30 cycles of $95{ }^{\circ} \mathrm{C}$ for 1 minute, $55^{\circ} \mathrm{C}$ for 1 minute and $72{ }^{\circ} \mathrm{C}$ for 1 minute, followed by a final extension at $72{ }^{\circ} \mathrm{C}$ for 5 minutes. The total PCR products were separated on a $1 \%$ agarose gel run at $5 \mathrm{~V} \mathrm{~cm}^{-1}$ for 1 hour in $1 \times$ Tris-borate-EDTA buffer. The gels were visualised using ethidium bromide staining and photography under UV light and the band at size equivalent to approximately $1050 \mathrm{bp}$ was excised and purified using a QIAGEN QIAquick Gel extraction kit (50 $\mu$ l final elution in SDW).

\section{Restriction fragment length polymorphism (RFLP) analysis}

Purified PCR products were digested separately with three restriction enzymes, BstU1, Hha1, Rsa1 (New England Biolabs). Digestions were completed in $15 \mu \mathrm{L}$ total reaction volume: $1.5 \mu \mathrm{L} 10 \mathrm{x}$ NEB buffer $4,0.15 \mu \mathrm{BSA}$ (Hha1 digestion), $5 \mu \mathrm{L}$ purified PCR product, $5 \mathrm{U}$ restriction enzyme, SDW to $15 \mu \mathrm{L}$, and digested at the recommended incubation temperatures for 6 hours. Following digestion the restriction products were separated on $3 \%$ agarose gels at $2.5 \mathrm{~V} \mathrm{~cm}^{-1}$ for 3 hours in $1 \mathrm{x}$ Tris-borateEDTA buffer. The gels were visualised using ethidium bromide staining and photography under UV light. Restriction fragment sizes were compared to a 100 bp ladder between every 6 samples. 
The gel images were analysed using TotalLab software (TL120 Nonlinear Dynamics) to assign sizes to the banding profiles and to cluster the RFLP profiles. The groupings were manually confirmed and grouped into operational taxonomic units (OTUs) defined as a group of endophytes which had identical banding patterns within each of the three independent enzyme digestions.

\section{Identification of isolates and statistical analysis of data}

Representatives of each OTU were selected for partial sequencing of the 16S rRNA gene (purified PCR product sent to MWG Eurofins for sequencing). Isolates with indistinct RFLP profiles were also sent for 16S rRNA gene sequencing. The closest identity for each OTU was established at the genus level by comparing sequences to the GenBank databases (www.ncbi.nlm.nih.gov/blast) using BLASTN. The partial 16S rRNA gene sequences for representatives of the OTUs obtained in this study were deposited in the GenBank database under the accession numbers KJ649707 - KJ649740 (Table 3). Rarefaction analysis was performed using the free statistical software PAST 3.x. (Hammer et al. 2001).

Endophyte population data were analysed using two methods. The first converted the colony observations to $\log _{10}(\mathrm{CFU}+1)$ per gram fresh weight of tissue to satisfy assumptions of normality for the parametric statistical tests used. The second method analysed the raw count data to provide proportional data for endophyte groups within each plant. Data were analysed using GenStat for Windows 14th Edition (VSN International).

In the first method a linear mixed model was used to analyse $\log _{10}(\mathrm{CFU}+1) \mathrm{g}^{-1} \mathrm{FW}$ data accounting for the design of the study having 3 sub-plots within each of the six Broadbalk plots (Nil, Nil plus $\mathrm{Mg}$ P K, 144 N, 288 N, FYM and FYM plus N), such that there were eighteen sub-plots in total. Each of these subplots were sampled twice (in May and then in July). This accounted for the random part of the model used. The model was fitted using the method of restricted maximum likelihood approach (REML) using a fixed part of the model as Treatment*Tissue*Time*Phylum. Where the * indicates that all main effects and interactions between the model factors should be tested. Model terms of statistical importance were investigated by comparing predicted means of biological interest using Fisher's least significant difference (LSD) test at $p=0.05$. Residual plots following this analysis confirmed that the modelling approach used was valid. Differences at a genus level were viewed using Correspondence Analysis. Correspondence Analysis (CoA) is similar to performing a Principal Components Analysis (PCA) on both the rows (genera) and the columns (plots or treatments) of the data matrix in such a way that the components from each analysis can be related (Digby and Kempton 
1987). The analysis is used to simultaneously display information about the rows and the columns on the same plot. In the present case this allows comparison of similarities between genera, of similarities between plots, and in particular, associations between genera and plots.

The second modelling approach used a generalised linear model (GLM) to analyse the raw colony observations from each plant. The proportions of six phyla in each random subset of bacterial colonies from each plant, where each subset had its own total number of observations, were modelled using a generalised linear model assuming a binomial distribution and a logit link function, $\left(\log _{10}(\mathrm{p} / 1-\mathrm{p})\right)$ where $\mathrm{p}$ is the proportion of the total colony observations per plant. The model fitted was Treatment*Tissue*Time*Phylum where the * indicates that all main effects and interactions between the model terms should be tested. This was performed using F-tests due to there being some overdispersion, ie. some extra variation in the data than would be expected for a binomial distribution. A summary of the REML and GLM test statistics is presented in the Supplementary data. 


\section{Results}

\section{Sampling analysis and summary of OTUs}

The cultured bacterial endophyte community of wheat was analysed for two tissue types (root and leaf), at two growth stages and under six fertiliser treatments. Culturable endophytic bacteria were isolated from 34 surface sterile plants in May and 30 surface sterile plants in July 2011. PCR and RFLP analysis of the 16S rRNA gene for 804 bacterial isolates revealed 28 OTUs (see Fig. 2 for agarose gel RFLP profiles for each OTU) which were subsequently identified to the genus level using 16 rRNA gene sequence analysis (Table 3). OTU incidence values showed that no one OTU was recovered from all plants sampled. The genus Pseudomonas was recovered at the highest incidence in the roots, found in $64 \%$ of plants. The genus Bacillus was recovered at the highest incidence in the leaves, occurring in $20 \%$ of plants.

To determine the effectiveness of sampling in identifying the total population OTUs, a rarefaction curve was plotted for each tissue type sampled. The rarefaction curve for the root OTUs nearly reached an asymptote indicating reasonable representation of the OTUs by our sampling (Fig. 3). In the leaves the rarefaction curves did not reach an asymptote, indicating poorer coverage. This was likely to be due to the lower number of colonies recovered from these samples (of the 804 colonies analysed only 184 were recovered from the leaves). As such our sampling of leaf endophytes did not provide such robust coverage of the rarer OTUs as the root sampling.

Species richness decreased from May to July and from root to leaves (Table 3). Total abundance of endophytes was significantly higher in the roots than the shoots (Table 4) and there was a small increase in abundance from May to July in both the roots and the shoots. At the genus level, the most abundant OTU remained constant from May to July (Table 3), but the identity of other abundant genera changed. In the roots, Pseudomonas remained the most prevalent genus in both May and July, but in May the second and third most prevalent genera were Flavobacterium and Variovorax, in July this had changed to Rhizobium and Pedobacter. In the leaves, Bacillus remained most prevalent in both May and July, but the second and third most prevalent genera changed from Polaromonas and Pseudomonas to Curtobacterium and Devosia. In this study, sample time was thus shown to also have influence at the genus level. 


\section{Tissue and phylum interaction}

REML analysis of endophyte abundances indicated there was a significant two way interaction between tissue type and phylum $\left(\mathrm{F}_{5,197}=11.55, \mathrm{p}<0.001\right)$ (Fig. 4a). Endophyte abundances in the leaves were lower than in the roots for all phyla except the Firmicutes $\left(\mathrm{p}<0.05, \mathrm{LSD}_{0.05}=0.715\right)$. The GLM analysis of raw colony observations also showed a significant two way interaction between tissue type and phylum $\left(\mathrm{F}_{25,480}=2.87, \mathrm{p}<0.001\right)$. This proportional analysis (Fig. $\left.4 \mathrm{~b}\right)$ showed that in the leaves the Gram-positive phyla (Actinobacteria and Firmicutes) were significantly higher in abundance than the Gram-negative phyla $(\mathrm{p}<0.05)$. Conversely in the roots the $\gamma$-proteobacteria dominated with significantly greater abundance than any other group $(p<0.05)$ and the Firmicutes were the least abundant group detected.

\section{Fertiliser treatment, sample time and phylum interaction}

REML analysis of endophyte abundance data showed a second significant interaction between treatment and phyla $\left(\mathrm{F}_{5,25}=11.55, \mathrm{p}<0.001\right)(\mathrm{Fig} .5)$. This indicated that phyla respond differently to the fertiliser treatments. For example the Actinobacteria had lower abundance in plants grown in the FYM treatment compared to abundance in plants grown in the inorganic $\mathrm{N}$ and the nil $\mathrm{N}$ treatments. In contrast, the $\beta$-proteobacteria occur at a higher abundance in the FYM and Nil treatments than in the inorganic $\mathrm{N}$ treatments. Mean endophyte numbers across all tissue types, sample times and phyla showed that there was a significantly higher abundance of endophytes in the Nil fertiliser treatment plot than in the other plots $\left(\mathrm{p}=0.013, \mathrm{LSD}_{0.05}=0.391\right)$ (Fig. 6).

The GLM analysis of the proportions of phyla for the subset of each plate indicated there was also a further significant interaction, in this case a three way interaction between sample time, treatment and phylum $\left(\mathrm{F}_{25,480}=2.87, \mathrm{p}<0.001\right)$ (Fig. 7a and $\left.7 \mathrm{~b}\right)$. Inclusion of sample time in this interaction indicates that the relative presence of a given phylum changes between May and July. For example in the $288 \mathrm{~N}$ treatment in May the $\gamma$-proteobacteria are the most prevalent group comprising greater than $60 \%$ of the isolates, whereas in July the $\gamma$-proteobacteria comprise less than $25 \%$ of the isolates. All other significant $(\mathrm{p}<0.05$, F-test) main effects and interactions in the REML and GLM analyses were subsumed by these main significant interactions. 


\section{Correspondence analysis}

Associations between fertiliser treatments and the interactions between OTUs (genera) and fertiliser treatments were examined using correspondence analysis (Fig. 8). We found that in the roots in May the endophytic community in the $288 \mathrm{~N}$ treatment was not associated with the other treatments. The fertiliser treatments $144 \mathrm{~N}$ and $\mathrm{Nil}+$ were also segregated from other fertiliser treatments (Fig. 8a). There were some associations between specific OTUs and these segregated treatments, $144 \mathrm{~N}$ was associated with Plantibacter and Curtobacterium, whereas treatment $288 \mathrm{~N}$ had strong associations with Arthrobacter and Agromyces. A number of OTUs also clustered close to the origin, indicating these OTUs were loosely associated with most treatments. Correspondence analysis for the roots in July showed different associations. Four of the fertiliser treatments, Nil, Nil +, FYM and 288 N, showed little distinction, clustering together on the correspondence plot (Fig. 8b). Only the inorganic $144 \mathrm{~N}$ and FYM $+\mathrm{N}$ treatments showed segregation from the other treatments. $144 \mathrm{~N}$ was associated with Pedobacter and Microbacterium and FYM + was strongly associated with the Commanadaceae family (Variovorax and Polaromonas), and Paenibacillus.

In the leaves there was a much lower incidence of colonisation and as such the correspondence analysis plots for May and July (Fig. 8c and 8d) are less robust than for the roots. The two Nil treatments have no association with each other in May, neither do the two inorganic $\mathrm{N}$ treatments, or the two FYM treatments.

The correspondence analysis indicated that there were associations of specific OTUs to fertiliser treatments, and these associations changed with plant growth stage. In the shoots there was an effect of fertiliser treatment at both the phylum and genus level, but due to the lower sampling coverage it is difficult to determine if these are valid trends or sampling effects. 


\section{Discussion}

\section{Endophyte isolation}

Accurate recovery of endophytes relies entirely on the stringency of the method used; therefore this study used a carefully optimised surface sterilisation method. This analysis found four phyla dominating the wheat endosphere; Proteobacteria, Bacteroidetes, Actinobacteria and Firmicutes. These phyla are all known to contain endophytic species and their presence has been confirmed in a number of culture and molecular studies (Bulgarelli et al. 2012; Ferrando et al. 2012; Lundberg et al. 2012). In a similar experiment, comparison of cultured endophyte genus richness compared to cultured rhizosphere genus richness showed that the latter was almost two fold higher (a total of 35 genera in the endosphere and 60 genera in the rhizosphere; unpublished data, Mauchline, Clark, Robinson and Hirsch). This demonstrates that the rhizosphere has greater genus richness than the endosphere even within limitations of culture dependent studies. The presence of culturable bacteria which are rhizosphere competent but are not found in the endosphere indicates either exclusion by the plant or a lack of bacterial endophytic competencies such as motility or adherence, as reviewed by Reinhold-Hurek and Hurek (2011).

\section{Analysis of endophyte abundance and relative proportions of phyla}

The REML analysis and the GLM analysis both contributed to the conclusions we can draw from these data. The REML analysis relates to abundance of endophytes within the plant tissue, while the GLM analysis relates solely to the relative contributions of phyla in the plants, irrespective of endophyte abundance. The GLM analysis therefore has slightly greater sensitivity to distinguish compositional changes without the variation introduced by differences in abundance of endophytes across treatments and plants. Both analysis methods indicated a similar interaction between tissue type and phylum. The Gram positive phyla, the Firmicutes and Actinobacteria, were high both in abundance and relative proportion in the shoot tissue. REML analysis revealed a significant interaction between treatment and phyla. This REML analysis also revealed a significant increase in endophyte densities in plants grown in the Nil treatment plot. This trend could not be revealed through the GLM analysis which analysed only the relative proportions of phyla. However, the GLM analysis of proportions revealed a further interaction between treatment, phyla and sample time. This time effect seen for the proportional data indicates that the profile over the treatments of relative presence for a given phylum changes between May and July. In this case the use of proportional data from the raw counts revealed a trend which was masked by the variation in endophyte abundance.

\section{The influence of tissue type on endophyte community}


Roots and leaves of wheat provide different biological niches and routes of colonisation for endophytes, it would thus be predicted that there were differences in abundance and community structure of endophytes in these tissues. As expected, the mean abundance of endophytic bacteria in the roots was significantly greater than in the leaves (Table 5 and Fig. $4 a$ ). This has also been found to be true in other agricultural crops, such as cotton, potato, maize and rice (Hallmann et al. 1997; Johnston-Monje and Raizada 2011; Mano et al. 2007; Sessitsch et al. 2002). Roots are a sink for photosynthetic carbon and are protected from extremes of temperature, solar radiation and moisture fluctuations, hence may provide more suitable niches for endophyte colonisation and establishment than the leaves.

It is interesting that the distribution of phyla differed significantly in the roots and leaves. Leaves may be colonised from inoculum established in the roots, but they can also be colonised directly from deposition of inoculum onto leaves through rain splash or air dispersal. The leaves had significantly higher abundances of the Gram-positive phyla, the Firmicutes and Actinobacteria, than the other phyla. Many species of these phyla are endospore forming and it may be that these are better adapted for survival in the leaf tissue, surviving the greater variation in environmental stresses and possibly better adapted for passage into reproductive tissue and longer term survival in seeds.

\section{The influence of sample time on endophyte community}

Other studies have shown a reduction in endophyte and epiphyte numbers through the plant growth season (Redford and Fierer 2009). This study showed a slight increase in the total abundance of endophytes from May to July. However, in this study the wheat plants were well established at both the points of sampling (May and July) and it is likely that the largest changes in endophyte abundance are observed between the seedling and mature stages. It is possible that the regulation of endophyte numbers is more tightly controlled in the established and mature plant and our sample time range was not wide enough to identify large changes. There was a significant interaction involving sample time in the GLM analysis of the proportion of phyla in plants. This showed that even at the broader level of phyla sample time influences endophyte community structures. This change through the growth season was even clearer at the genus level, as shown through correspondence analysis. These changes between sample times may relate to changes in bacterial niche establishment as the plant grows, to changes in nutrient availability through the growth season, or to environmental changes between May and July.

\section{The influence of fertiliser treatment effect on endophyte community}


This study found significantly higher wheat bacterial endophyte abundances in the Nil treatment plot than the other treatment plots. This is in contrast to the number of soil bacteria inferred from bacterial 16S rRNA genes which showed no significant differences in abundance between these Broadbalk fertiliser treatments (Clark et al. 2012). There is an increase in release organic acids into the rhizosphere of nutrient stressed plants (Lopez Brucio et al. 2000) and thus may be attracting and supporting higher numbers of endophytes. Alternatively the nutrient stressed plant may harbour more latent or active pathogens which may appear to elevate endophyte counts. Evolutionary theory has also suggested that mutually beneficial symbiotic relationships are more likely to develop in poor quality environmental landscapes (Thrall et al. 2006). Thus it may be that the higher abundance of endophytes is a result of the long term interaction between the endophytes and the plant in the low nutrient treatment. Such an interaction may suggest that endophytes found in the nutrient stressed plants are the best candidates for providing endophytic traits beneficial to the host plant.

This study showed that fertiliser treatments alter endophytic communities at both the phylum and genus level. If endophyte communities were solely determined by plant growth we might expect to see the endophyte communities grouped by total available nitrogen input. However, the correspondence analysis did not show any notable similarities at the genus level between groups of treatments by nitrogen input. For example, correspondence analysis at the genus level shows that the endophytic community in the highest inorganic nitrogen treatment $(288 \mathrm{~N})$ is distinct in the roots in May, while the Nil+ treatment and the $144 \mathrm{~N}$ cluster together. These data might suggest that there are differences in the endophytic bacterial populations in wheat which are driven by the soil bacterial community rather than plant growth.

The relative strength of the influence of soil properties and plant genotype on the endophytic community varies between plant species and cultivars. In rice it appears that plant genotype is a stronger determinant of endophytic community than soil type (explaining $48.8 \%$ of variation compared to $36.6 \%$ of variation) (Hardoim et al. 2011). In contrast in Arabidopsis thaliana, a noncrop species, both Bulgarelli et al., (2012) and Lundberg et al., (2012) found that soil type has a stronger influence on the endophytic community than does plant genotype. This may suggest that there may be a stronger plant genotype effect for the cultivated crop species which have been bred for specific agricultural traits. 


\section{Possible influences of soil properties on endophyte recruitment and community structure}

While the conclusions from this study demonstrate that tissue type, sample time and fertiliser treatment all influence the community structure of bacterial endophytes in wheat, the possible mechanisms through which fertiliser treatments are altering the endophyte community structure cannot be separated. It is known that changes in soil properties can lead to changes in the soil bacterial community (Lauber et al. 2008; Marschner et al. 2003). Indeed this was shown to be true in a recent comparison of the soil microbial community of the agricultural and woodland plots of the Broadbalk experiment (Zhalnina et al. 2013). It follows that where fertiliser inputs change soil bacterial communities, we might expect to see these changes reflected in the endophytic community (Seghers et al. 2004).

It is also known that plants have a direct influence on the soil and rhizosphere microbial communities (Turner et al. 2013) and that fertiliser inputs can alter plant growth responses particularly with respect to root exudation (Lopez Brucio et al. 2000). Changes in plant root exudates, working with the plant defence system, may therefore act as a plant mediated selection mechanism for endophyte colonisation. Thus fertiliser treatments may also be acting indirectly on the endophytic community through the plant growth response.

This suggests two mechanisms through which fertiliser treatment may alter the endophytic community (Fig. 9):

1) Fertilisers may directly alter the soil bacterial community hence altering the available pool from which bacteria colonise the plant

2) Fertilisers may alter plant growth and/or exudates thereby impacting on recruitment of the endophytic community

\section{Conclusions}

In conclusion, robust isolation techniques and stringent controls are critical for accurate recovery of endophytes. As expected there was a significant effect of tissue type on endophyte abundance and on the relative presence of each phylum within the endophyte community. There was a significantly higher abundance of bacterial endophytes in the Nil treatment plots, a trend not seen in soil bacterial abundances. This may be the result of increased mutually beneficial evolutionary symbionts occurring in a nutrient poor environment, or may be the results of increased root exudates from nutrient stressed plants. The endophytes in these nutrient stressed plants may provide traits beneficial to the host plant. 
In the GLM analysis of the proportions of raw count data, we found an interaction between phylum, time and treatment. This was confirmed in the distinctions shown in the correspondence analysis. It seems likely that both the wheat growth response and the soil bacterial community contribute to the composition of the endophytic bacterial community in wheat. This leads to important conclusions for the application of endophytes to agricultural crops or the management of cultivation regimes to favour beneficial endophytes. Inoculation of endophytes to soil is unlikely to be successful unless the endophyte for inoculation is adapted to the plant genotype. Fertiliser applications may also reduce the effectiveness of applications by reducing the population densities of endophytes in the fertilised plants. This suggests that there may be a narrower effective niche for application than had been previously suggested and further studies are needed. Augmenting and utilising indigenous endophytes may be the most effective method for application in a field situation and this could be combined with genetic manipulation for addition of beneficial traits to specific endophytic strains

Acknowledgments

We are grateful to the Biotechnology and Biological Sciences Research Council (BBSRC) and to Novozymes for providing the funding for a PhD studentship for R. Robinson. We would particularly like to thank Dr Stephen Powers (Rothamsted Research) for his help and advice with statistical analysis and Dr Ben Raymond (Imperial College) for statistical advice and recommendations.

\section{References}

Barroso JM (2011) Regulations: Commission implementing regulation (EC) No 1107/2009 of the the European Parliament and of the council as regards the list of approved active substances. Official Journal of the European Union 153.

Bodenhausen N, Horton MW, Bergelson J (2013) Bacterial communities associated with the leaves and the roots of Arabidopsis thaliana. PLoS ONE 8: e56329. doi: 10.1371/journal.pone.0056329.

Bulgarelli D, Rott M, Schlaeppi K, Ver Loren van Themaat E, Ahmadinejad N, Assenza F, Rauf P, Huettel B, Reinhardt R, Schmelzer E, Peplies J, Gloeckner FO, Amann R, Eickhorst T, Schulze-Lefert P (2012) Revealing structure and assembly cues for Arabidopsis rootinhabiting bacterial microbiota. Nature 488: 91-95. doi: 10.1038/nature11336.

Chelius MK, Triplett EW (2001) The Diversity of Archaea and Bacteria in Association with the Roots of Zea mays L. Microb Ecol 41: 252-263. doi: 10.1007/s002480000087.

Clark IM, Buchkina N, Jhurreea D, Goulding KW, Hirsch PR (2012) Impacts of nitrogen application rates on the activity and diversity of denitrifying bacteria in the Broadbalk Wheat Experiment. Philos Trans R Soc Lond B Biol Sci 367: 1235-1244. doi: 10.1098/rstb.2011.0314.

Cole JR, Wang Q, Cardenas E, Fish J, Chai B, Farris RJ, Kulam-Syed-Mohideen AS, McGarrell DM, Marsh T, Garrity GM, Tiedje JM (2009) The Ribosomal Database Project: improved alignments and new tools for rRNA analysis. Nucleic Acids Res 37: D141-145. doi: 10.1093/nar/gkn879.

de Santi Ferrara FI, Oliveira ZM, Gonzales HHS, Floh EIS, Barbosa HR (2012) Endophytic and rhizopheric enterobacteria isolated from sugar cane have different potentials for producing 
plant growth-promoting sunstances. Plant Soil 353: 409-417. doi: 10.1007/s11104-011-10421.

Digby PGN, Kempton RA (1987) Multivariate analysis of ecological communities. Chapmann and Hall, London.

Ferrando L, Fernandez Manay J, Fernandez Scavino A (2012) Molecular and culture-dependent analyses revealed similarities in the endophytic bacterial community composition of leaves from three rice (Oryza sativa) varieties. FEMS Microbiol Ecol 80: 696-708. doi: 10.1111/j.1574-6941.2012.01339.x.

Glick BR, Todorovic B, Czarny J, Cheng Z, Duan J, McConkey B (2007) Promotion of Plant Growth by Bacterial ACC Deaminase. Crit Rev Plant Sci 26: 227-242. doi: 10.1080/07352680701572966.

Gupta M, Kiran S, Gulati A, Singh B, Tewari R (2012) Isolation and identification of phosphate solubilizing bacteria able to enhance the growth and aloin-A biosynthesis of Aloe barbadensis Miller. Microbiol Res 167: 358-363. doi: 10.1016/j.micres.2012.02.004.

Hallmann J, Quadt-Hallmann A, Mahaffee WF, Kloepper JW (1997) Bacterial endophytes in agricultural crops. Can J Microbiol 43: 895-914.

Hammer Ø, Harper DAT, Ryan PD (2001) PAST: Paleontological statistics software package for education and data analysis. Paleontologia Electronica 4: 9.

Hardoim PR, Andreote FD, Reinhold-Hurek B, Sessitsch A, van Overbeek LS, van Elsas JD (2011) Rice root-associated bacteria: insights into community structures across 10 cultivars. FEMS Microbiol Ecol 77: 154-164. doi: 10.1111/j.1574-6941.2011.01092.x.

Hardoim PR, van Overbeek LS, van Elsas JD (2008) Properties of bacterial endophytes and their proposed role in plant growth. Trends Microbiol 16: 463-471. doi: 10.1016/j.tim.2008.07.008

Johnston-Monje D, Raizada MN (2011) Conservation and diversity of seed associated endophytes in Zea across boundaries of evolution, ethnography and ecology. PLoS ONE 6: e20396. doi: 10.1371/journal.pone.0020396.

Kembel SW, Wu m, Eisen JA, Green JL (2012) Incorporating 16S gene copy number information improves estimates of microbial diversity and abundance. PLoS Comp Biol 8. doi: 10.1371/journal.pcbi.1002743.g001.

Klindworth A, Pruesse E, Schweer T, Peplies J, Quast C, Horn M, Glockner FO (2013) Evaluation of general 16S ribosomal RNA gene PCR primers for classical and next-generation sequencingbased diversity studies. Nucleic Acids Res 41. doi: 10.1093/nar/gks808.

Lauber CL, Strickland MS, Bradford MA, Fierer N (2008) The influence of soil properties on the structure of bacterial and fungal communities across land-use types. Soil Biol Biochem 40: 2407-2415. doi: 10.1016/j.soilbio.2008.05.021.

Lopez BR, Tinoco-Ojanguren C, Bacilio M, Mendoza A, Bashan Y (2012) Endophytic bacteria of the rock-dwelling cactus Mammillaria fraileana affect plant growth and mobilization of elements from rocks. Environ Exp Bot 81: 26-36. doi: 10.1016/j.envexpbot.2012.02.014.

Lopez Brucio J, Nieto-Jacobo M, Ramirez-Rodriguez V, Herrera-Estrella L (2000) Organic acid metabolism in plants: from adaptive physiology to transgenic varieties for cultivation in extreme soils. Plant Sci 160: 1-13.

Lundberg DS, Lebeis SL, Paredes SH, Yourstone S, Gehring J, Malfatti S, Tremblay J, Engelbrektson A, Kunin V, del Rio TG, Edgar RC, Eickhorst T, Ley RE, Hugenholtz P, Tringe SG, Dangl JL (2012) Defining the core Arabidopsis thaliana root microbiome. Nature 488: 86-90. doi: 10.1038/nature11237.

Mano H, Tanaka F, Nakamura C, Kaga H, Morisaki H (2007) Culturable endophytic bacterial flora of the maturing leaves and roots of rice plants (Oryza sativa) cultivated in a paddy field. Microbes Environ 22: 175-185.

Marchesi JR, Sato T, Weightman AJ, Martin TA, Fry JC, Hiom SJ, Wade WG (1998) Design and evaluation of useful bacterium-specific PCR primers that amplify genes coding for bacterial 16S rRNA. Appl Environ Microbiol 64: 795.

Marschner P, Kandeler E, Marschner B (2003) Structure and function of the soil microbial community in a long-term fertilizer experiment. Soil Biol Biochem 35: 453-461. doi: 10.1016/s0038-0717(02)00297-3. 
Monteiro RA, Balsanelli E, Wassem R, Marin AM, Brusamarello-Santos LCC, Schmidt MA, TadraSfeir MZ, Pankievicz VCS, Cruz LM, Chubatsu LS, Pedrosa FO, Souza EM (2012) Herbaspirillum-plant interactions: microscopical, histological and molecular aspects. Plant Soil 356: 175-196. doi: 10.1007/s11104-012-1125-7.

Muyzer G, de Waal EC, Uitterlinden AG (1993) Profiling of complex microbial populations by denaturing gradient gel electrophoresis analysis of polymerase chain reaction amplified genes coding for 16S rRNA. Appl Environ Microbiol 59: 695-700.

OECD/FAO (2011) OECD-FAO Agricultural Outlook 2011-2020. OECD Publishing and FAO.

Olesen JE, Trnka M, Kersebaum KC, Skjelvåg AO, Seguin B, Peltonen-Sainio P, Rossi F, Kozyra J, Micale F (2011) Impacts and adaptation of European crop production systems to climate change. European Journal of Agronomy 34: 96-112. doi: 10.1016/j.eja.2010.11.003.

Osborn AM, Moore ER, Timmis KN (2000) An evaluation of terminal-restriction fragment length polymorphism (T-RFLP) analysis for the study of microbial community structure and dynamics. Environ Microbiol 2: 39-50.

Pavlo A, Leonid O, Iryna Z, Natalia K, Maria PA (2011) Endophytic bacteria enhancing growth and disease resistance of potato (Solanum tuberosum L.). Biol Control 56: 43-49. doi: 10.1016/j.biocontrol.2010.09.014.

Pineda A, Zheng SJ, van Loon JJ, Dicke M (2012) Rhizobacteria modify plant-aphid interactions: a case of induced systemic susceptibility. Plant Biol 14: 83-90. doi: 10.1111/j.14388677.2011.00549.x.

Ramesh R, Joshi AA, Ghanekar MP (2009) Pseudomonads: major antagonistic endophytic bacteria to suppress bacterial wilt pathogen, Ralstonia solanacearum in the eggplant (Solanum melongena L.). World J Microbiol Biotechnol 25: 47-55.

Redford AJ, Fierer N (2009) Bacterial succession on the leaf surface: a novel system for studying successional dynamics. Microb Ecol 58: 189-198. doi: 10.1007/s00248-009-9495-y.

Rees RM, Baddeley JA, Bhogal A, Ball BC, Chadwick DR, Macleod M, Lilly A, Pappa VA, Thorman RE, Watson CA, Williams JR (2013) Nitrous oxide mitigation in UK agriculture. Soil Sci Plant Nutr 59: 3-15. doi: 10.1080/00380768.2012.733869.

Reinhold-Hurek B, Hurek T (2011) Living inside plants: bacterial endophytes. Curr Opin Plant Biol 14: 435-443. doi: 10.1016/j.pbi.2011.04.004.

Ren J-H, Li H, Wang Y-F, Ye J-R, Yan A-Q, Wu X-Q (2013) Biocontrol potential of an endophytic Bacillus pumilus JK-SX001 against poplar canker. Biol Control 67: 421-430. doi: 10.1016/j.biocontrol.2013.09.012.

Rothamsted (2006) Guide to the classical and other long-term experiments, datasets and sample archive. Lawes Agricultural Trust Co. Ltd.

Seghers D, Wittebolle L, Top EM, Verstraete W, Siciliano SD (2004) Impact of agricultural practices on the Zea mays L. endophytic community. Appl Environ Microbiol 70: 1475-1482. doi: 10.1128/aem.70.3.1475-1482.2004.

Sessitsch A, Reiter B, Pfeifer U, Wilhelm E (2002) Cultivation-independent population analysis of bacterial endophytes in three potato varieties based on eubacterial and Actinomyces-specific PCR of 16S rRNA genes. FEMS Microbiol Ecol 39: 23-32.

Thaweenut N, Hachisuka Y, Ando S, Yanagisawa S, Yoneyama T (2010) Two seasons' study on nifH gene expression and nitrogen fixation by diazotrophic endophytes in sugarcane (Saccharum spp. hybrids): expression of nifH genes similar to those of rhizobia. Plant Soil 338: 435-449. doi: 10.1007/s11104-010-0557-1.

Thrall PH, Hochberg ME, Burdon JJ, D BJ (2006) Coevolution of symbiotic mutualists and parasites in a community context. Trends Ecol Evol 22.

Turner TR, Ramakrishnan K, Walshaw J, Heavens D, Alston M, Swarbreck D, Osbourn A, Grant A, Poole PS (2013) Comparative metatranscriptomics reveals kingdom level changes in the rhizosphere microbiome of plants. Isme J 7: 2248-2258. doi: 10.1038/ismej.2013.119.

van Grinsven HJM, Spiertz JHJ, Westhoek HJ, Bouwman AF, Erisman JW (2013) Nitrogen use and food production in European regions from a global perspective. The Journal of Agricultural Science Nitrogen Workshop Special Issue Paper: 1-11. doi: 10.1017/s0021859613000853.

Watts CW, Clark LJ, Poulton PR, Powlson DS, Whitmore AP (2006) The role of clay, organic carbon and long-term management on mouldboard plough draught measured on the Broadbalk wheat 
experiment at Rothamsted. Soil Use and Management 22: 334-341. doi: 10.1111/j.14752743.2006.00054.x.

Wilson D (1995) Endophyte: The evolution of a term, and clarification of its use and definition. Oikos 73: 274-276.

Zhalnina K, de Quadros PD, Gano KA, Davis-Richardson A, Fagen JR, Brown CT, Giongo A, Drew JC, Sayavedra-Soto LA, Arp DJ, Camargo FA, Daroub SH, Clark IM, McGrath SP, Hirsch PR, Triplett EW (2013) Ca. Nitrososphaera and Bradyrhizobium are inversely correlated and related to agricultural practices in long-term field experiments. Front Microbiol 4: 104. doi: 10.3389/fmicb.2013.00104. 
Table 1 Summary of fertiliser treatments applied to Broadbalk plots for sampling of wheat plants

\begin{tabular}{|c|c|}
\hline Broadbalk plot & Annual treatment per hectare \\
\hline $2.1(F Y M+)$ & Farm yard manure $(\mathrm{FYM})^{\mathrm{a}}$ and $96 \mathrm{~kg} \mathrm{~N}^{\mathrm{b}}$ \\
\hline 2.2 (FYM) & $\mathrm{FYM}^{\mathrm{a}}$ \\
\hline 3 (Nil) & Nil (only atmospheric nitrogen deposition) \\
\hline $5 \quad(\mathrm{Nil}+)$ & $(P)^{c} K^{d} M g^{e}$ \\
\hline $8(144 N)$ & $144 \mathrm{~kg} \mathrm{~N}^{\mathrm{b}}(\mathrm{P})^{\mathrm{c}} \mathrm{K}^{\mathrm{d}} \mathrm{Mg}^{\mathrm{e}}$ \\
\hline $16(288 N)$ & $288 \mathrm{~kg} \mathrm{~N}^{\mathrm{b}}(\mathrm{P})^{\mathrm{c}} \mathrm{K}^{\mathrm{d}} \mathrm{Mg}^{\mathrm{e}}$ \\
\hline
\end{tabular}

${ }^{a}$ Farm Yard Manure at $35 \mathrm{t}$ since 1885

${ }^{\mathrm{b}} \mathrm{N}$ as ammonium nitrate since 1986

${ }^{c} \mathrm{P}$ as $35 \mathrm{~kg}$ triple superphosphate applied until 2000

${ }^{\mathrm{d}} \mathrm{K}$ as $90 \mathrm{~kg}$ potassium sulphate

e Mg $12 \mathrm{~kg}$ as Kieserite

Table 2 Plants used for endophyte isolation from each fertiliser treatment for May and July. Twelve plants per treatment (four per subplot) at each growth stage were processed. Samples with nonsterile controls were discarded. Bacterial isolates were only analysed from plants with sterile surface controls for both the root and leaf tissue.

\begin{tabular}{lll}
\hline $\begin{array}{l}\text { Broadbalk } \\
\text { plot }\end{array}$ & $\begin{array}{l}\text { Number of plants per subplot which } \\
\text { were suitable for further analysis of } \\
\text { endophyte isolates }\end{array}$ \\
\cline { 2 - 3 } & May & July \\
\hline $\mathbf{2 . 1}$ & $(3)(1)(0)$ & $(3)(1)(2)$ \\
$\mathbf{2 . 2}$ & $(2)(2)(2)$ & $(2)(1)(0)$ \\
$\mathbf{3}$ & $(2)(2)(4)$ & $(0)(2)(3)$ \\
$\mathbf{5}$ & $(2)(2)(2)$ & $(3)(2)(0)$ \\
$\mathbf{8}$ & $(3)(1)(1)$ & $(3)(2)(1)$ \\
$\mathbf{1 6}$ & $(2)(1)(2)$ & $(2)(1)(2)$ \\
\hline Total & 34 & 30 \\
plants & & \\
\hline
\end{tabular}


Table 3. OTUs identified to the genus and phylum or subclass level. GenBank accession numbers for a partial 16S rRNA gene sequence for a representative for each OTU are given. Mean abundance of OTUs in the root and leaf tissue in May and July are shown as CFU g ${ }^{-1} \mathrm{FW}$. The number of plants from which each OTU was isolated, the colonisation incidence value, is indicated in brackets giving a measure of the variation for each mean.

\begin{tabular}{|c|c|c|c|c|c|c|c|c|c|c|c|}
\hline \multirow{4}{*}{$\frac{\text { OTU }}{\text { OTU } 1}$} & \multirow{4}{*}{$\begin{array}{l}\text { OTU identity (to } \\
\text { genus level) }^{c} \\
\text { Agrobacterium }\end{array}$} & \multirow{4}{*}{\multicolumn{2}{|c|}{$\begin{array}{l}\text { Accession } \\
\text { Phylum or group number } \\
\text { a-proteobacteria JK649707 }\end{array}$}} & \multicolumn{8}{|c|}{ Mean CFU g $g^{-1} \mathrm{FW}$} \\
\hline & & & & \multicolumn{4}{|c|}{ Root endophyte } & \multicolumn{4}{|c|}{ Leaf endophyte } \\
\hline & & & & \multicolumn{2}{|l|}{$\overline{\text { May }^{a}}$} & \multicolumn{2}{|l|}{ July $^{\mathrm{b}}$} & \multicolumn{2}{|c|}{ May $^{a}$} & \multicolumn{2}{|c|}{ July $^{\mathrm{b}}$} \\
\hline & & & & 156 & $(1)$ & 1694 & (2) & 0 & $(0)$ & 0 & (0) \\
\hline OTU 2 & Bradyrhizobium & $\alpha$-proteobacteria & a JK649708 & 33 & $(1)$ & 0 & (0) & 0 & $(0)$ & 0 & (0) \\
\hline OTU 3 & Brevundimonas & $\alpha$-proteobacteria & JK649709 & 194 & (2) & 521 & (3) & 0 & $(0)$ & 3 & (1) \\
\hline OTU 4 & Caulobacter & a-proteobacteria & a JK649710 & 28 & $(1)$ & 0 & (0) & 0 & $(0)$ & 0 & (0) \\
\hline OTU 5 & Devosia & a-proteobacteria & JK649711 & 250 & (3) & 1022 & (8) & 56 & (2) & 463 & (1) \\
\hline OTU 6 & Rhizobium & $\alpha$-proteobacteria & JK649712 & 750 & $(4)$ & 7377 & $(17)$ & 28 & $(1)$ & 60 & (2) \\
\hline OTU 7 & Sphingomonas & a-proteobacteria & JK649713 & 167 & (3) & 193 & (1) & 14 & (2) & 28 & (1) \\
\hline OTU 8 & Duganella & $\beta$-proteobacteria & JK649714 & 0 & $(0)$ & 597 & (2) & 0 & $(0)$ & 0 & (0) \\
\hline OTU 9 & Polaromonas & $\beta$-proteobacteria & JK649715 & 306 & (3) & 4167 & (1) & 358 & (2) & 0 & (0) \\
\hline OTU 10 & Variovorax & $\beta$-proteobacteria & JK649716 & 1653 & $(4)$ & 5916 & $(12)$ & 22 & (1) & 0 & (0) \\
\hline OTU 11 & Pseudomonas & Y-proteobacteria & JK649718 & 23074 & $4(22)$ & 50295 & $5(19)$ & 161 & (3) & 3 & (1) \\
\hline OTU 12 & Serratia & v-proteobacteria & JK649722 & 986 & $(2)$ & 3801 & (5) & 0 & $(0)$ & 39 & (2) \\
\hline OTU 13 & Stenotrophomona & Y-proteobacteria & JK649723 & 375 & (2) & 0 & (0) & 0 & $(0)$ & 0 & (0) \\
\hline OTU 14 & Aeromicrobium & Actinobacteria & JK649724 & 56 & $(1)$ & 0 & (0) & 19 & (1) & 0 & (0) \\
\hline OTU 15 & Agreia & Actinok & JK649725 & 899 & (8) & 576 & (4) & 79 & $(7)$ & 65 & (2) \\
\hline OTU 16 & Agromyces & Actinobacteria & JK649726 & 139 & (3) & 0 & (0) & 6 & (2) & 42 & (1) \\
\hline OTU 17 & Arthrobacter & Actinobacteria & JK649727 & 1102 & (5) & 0 & $(0)$ & 3 & $(1)$ & 0 & (0) \\
\hline OTU 18 & Cellulomonas & Actinobacteria & JK649728 & 0 & $(0)$ & 0 & (0) & 3 & (1) & 0 & (0) \\
\hline OTU 19 & Curtobacterium & Actinobacteria & JK649729 & 34 & $(1)$ & 332 & (3) & 0 & $(0)$ & 1100 & (4) \\
\hline OTU 20 & Glycomyces & Actinobacteria & JK649730 & 194 & (3) & 0 & $(0)$ & 0 & $(0)$ & 0 & (0) \\
\hline OTU 21 & Microb & Actinobacteria & JK649731 & 788 & $(9)$ & 2819 & $(12)$ & 39 & (2) & 208 & (4) \\
\hline OT & Pla & Actinob & JK649734 & 19 & $(1)$ & 611 & $(2)$ & 11 & $(2)$ & 51 & (1) \\
\hline OTU 23 & Rhodococcus & Actinobacteria & JK649735 & 444 & $(4)$ & 0 & $(0)$ & 86 & (2) & 0 & (0) \\
\hline OTU 24 & Chryseobacterium & Bacteroidetes & JK649736 & 28 & $(1)$ & 0 & $(0)$ & 3 & $(1)$ & 0 & (0) \\
\hline OTU 25 & Flavobacterium & Bacteroidetes & JK649737 & 7847 & $(11)$ & 781 & (4) & 0 & $(0)$ & 5 & (1) \\
\hline OTU 26 & Pedobacter & Bacteroidetes & JK649738 & 102 & (3) & 7024 & (4) & 94 & (1) & 0 & (0) \\
\hline OTU 27 & Bacillus & Firmicutes & JK649739 & 240 & (2) & 37 & (1) & 802 & $(6)$ & 2638 & (7) \\
\hline \multirow[t]{2}{*}{ OTU 28} & Paenibacillus & Firmicutes & JK649740 & 0 & $(0)$ & 1556 & (3) & 9 & (1) & 90 & (3) \\
\hline & & OTU richness & & 26 & & 19 & & 18 & & 15 & \\
\hline
\end{tabular}


${ }^{a}$ mean values calculated from 34 plants

${ }^{\mathrm{b}}$ mean values calculated from 30 plants

${ }^{\mathrm{C}}$ Genera identified by sequencing of an approximately 1050bp fragment of the 16S rRNA gene and named as the closest match using the Seqmatch function in the Ribosomal Database Project (RDP-11)

CFU: colony forming unit

FW: fresh weight of plant tissue

Table 4. Total mean endophyte abundances associated with roots and leaves.

\begin{tabular}{llll}
\hline $\begin{array}{l}\text { Sample } \\
\text { time }\end{array}$ & Tissue & $\begin{array}{l}\text { Mean endophyte abundance } \\
\log \mathbf{1 0}\left(\mathrm{CFU}+\mathbf{1} \mathbf{~ g}^{-1} \mathbf{~} \mathbf{W}\right)\end{array}$ & Standard error \\
\hline May & Root & 4.391 & 0.112 \\
& Leaf & 2.174 & 0.340 \\
\hline July & Root & 4.642 & 0.134 \\
& Leaf & 2.750 & 0.364 \\
\hline
\end{tabular}




\section{Figures}

Figure 1

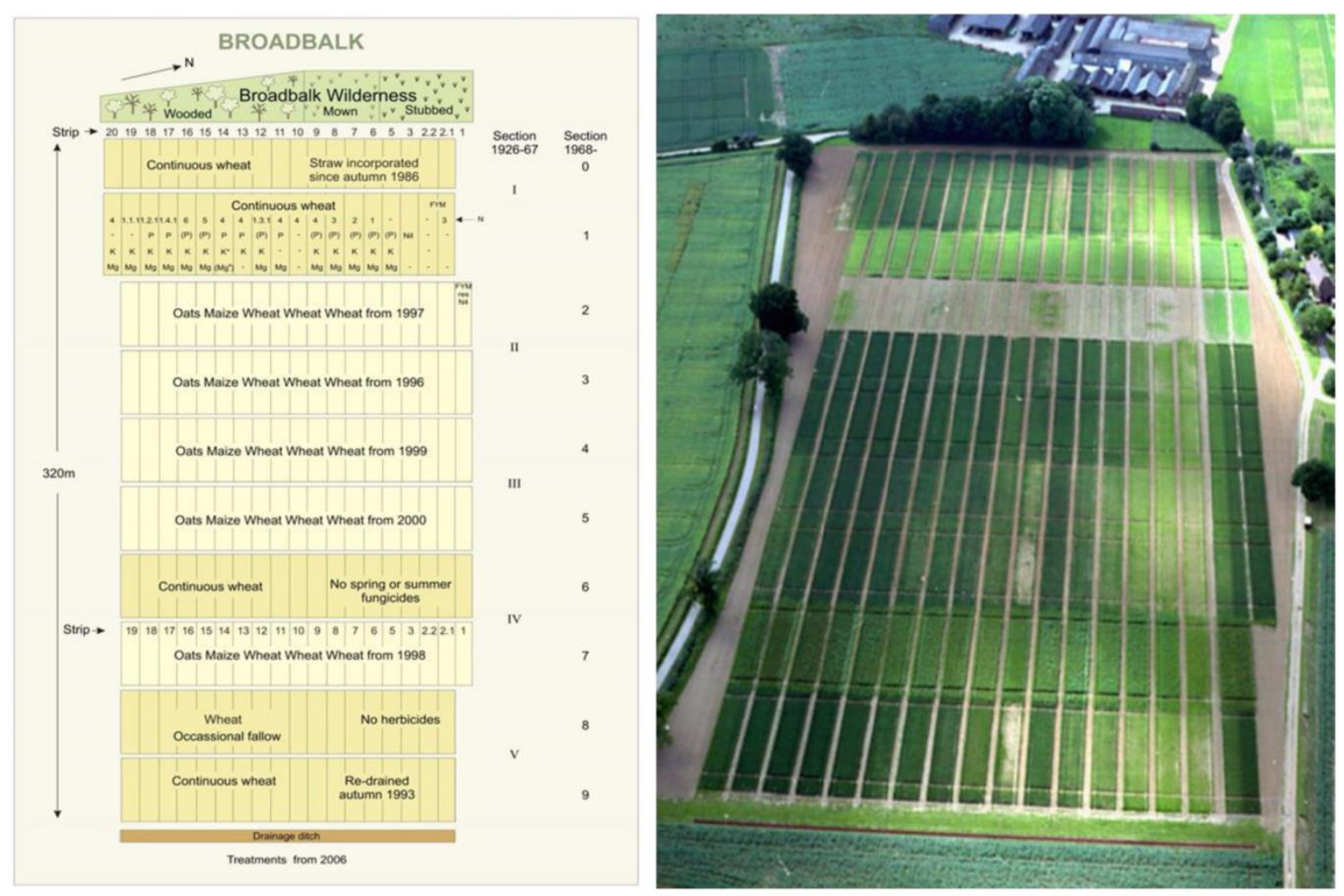


Figure 2
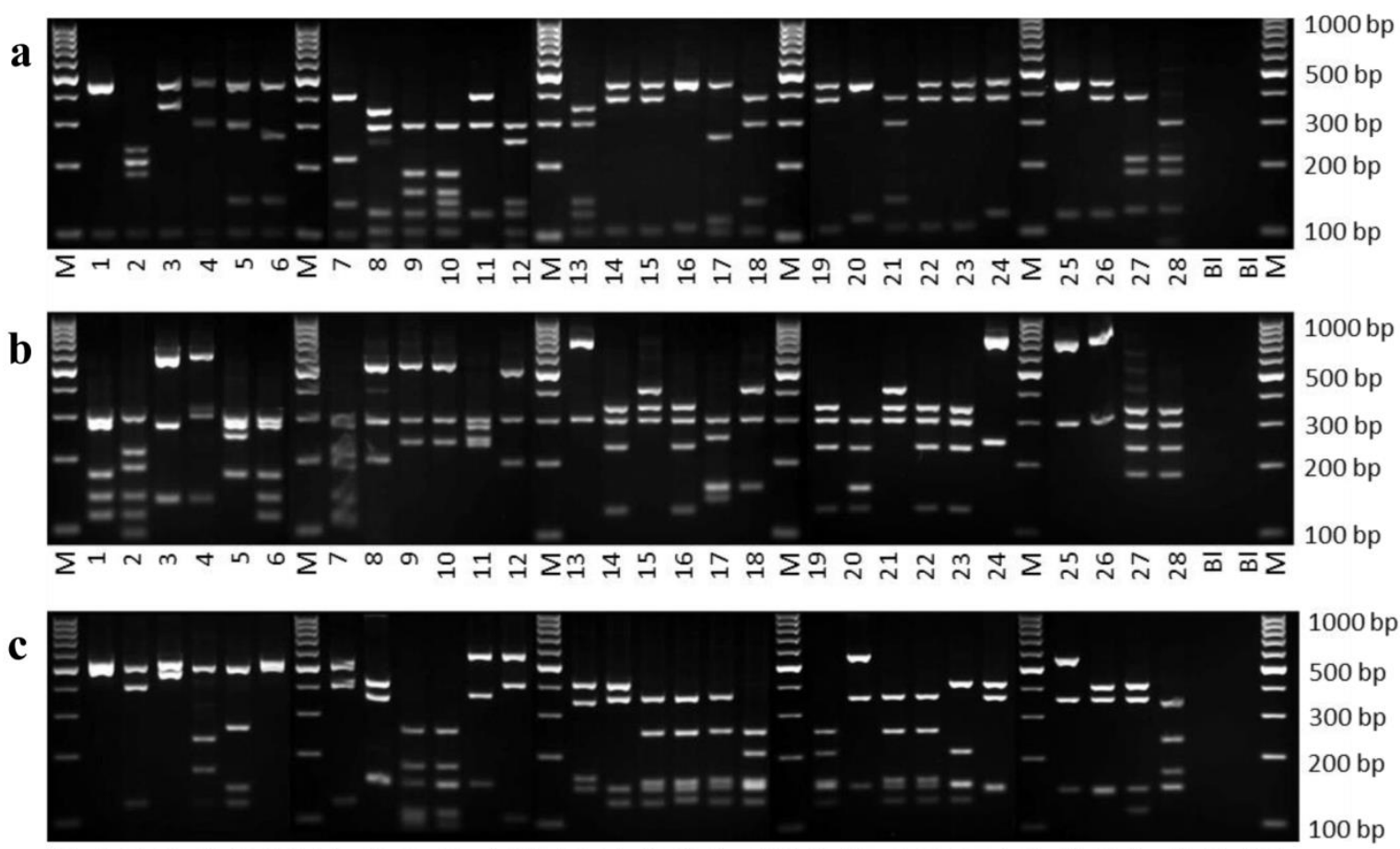

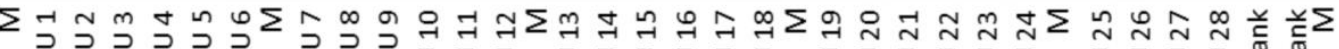

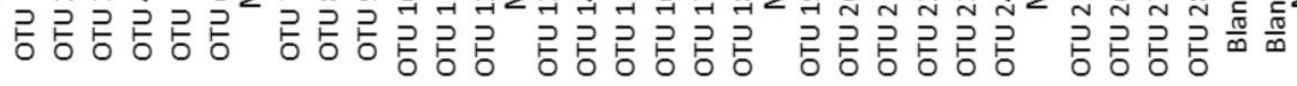


Figure 3

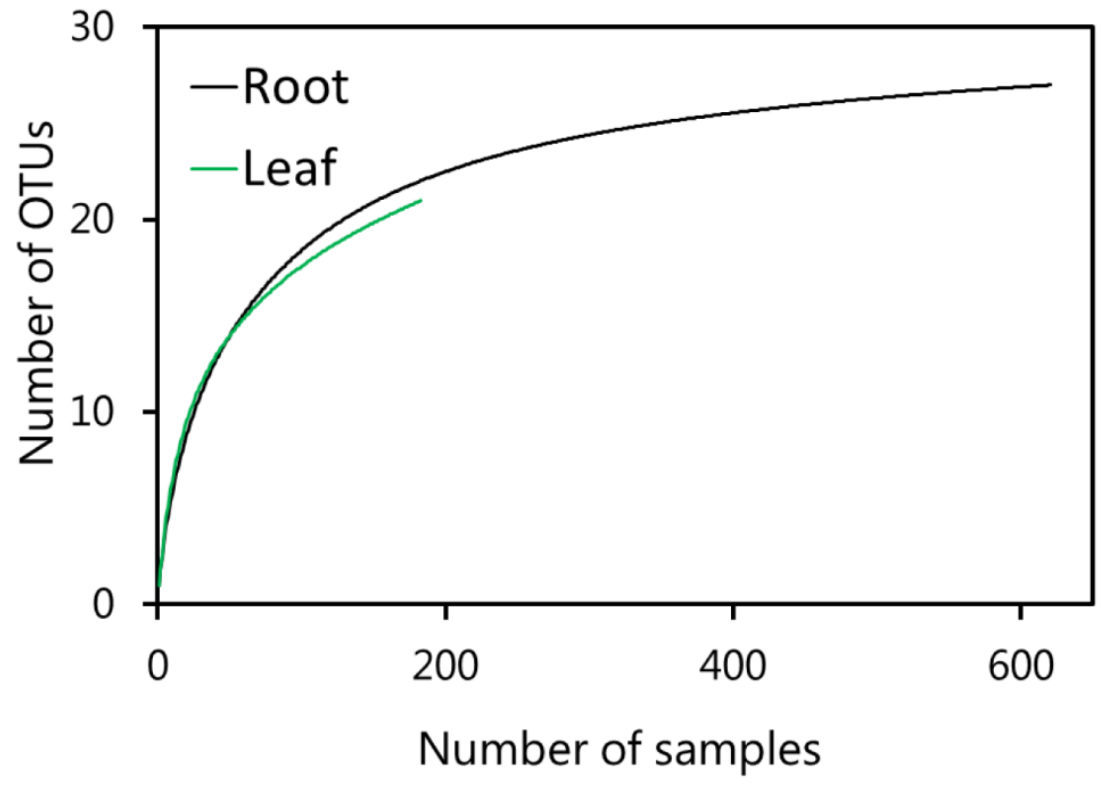


Figure 4
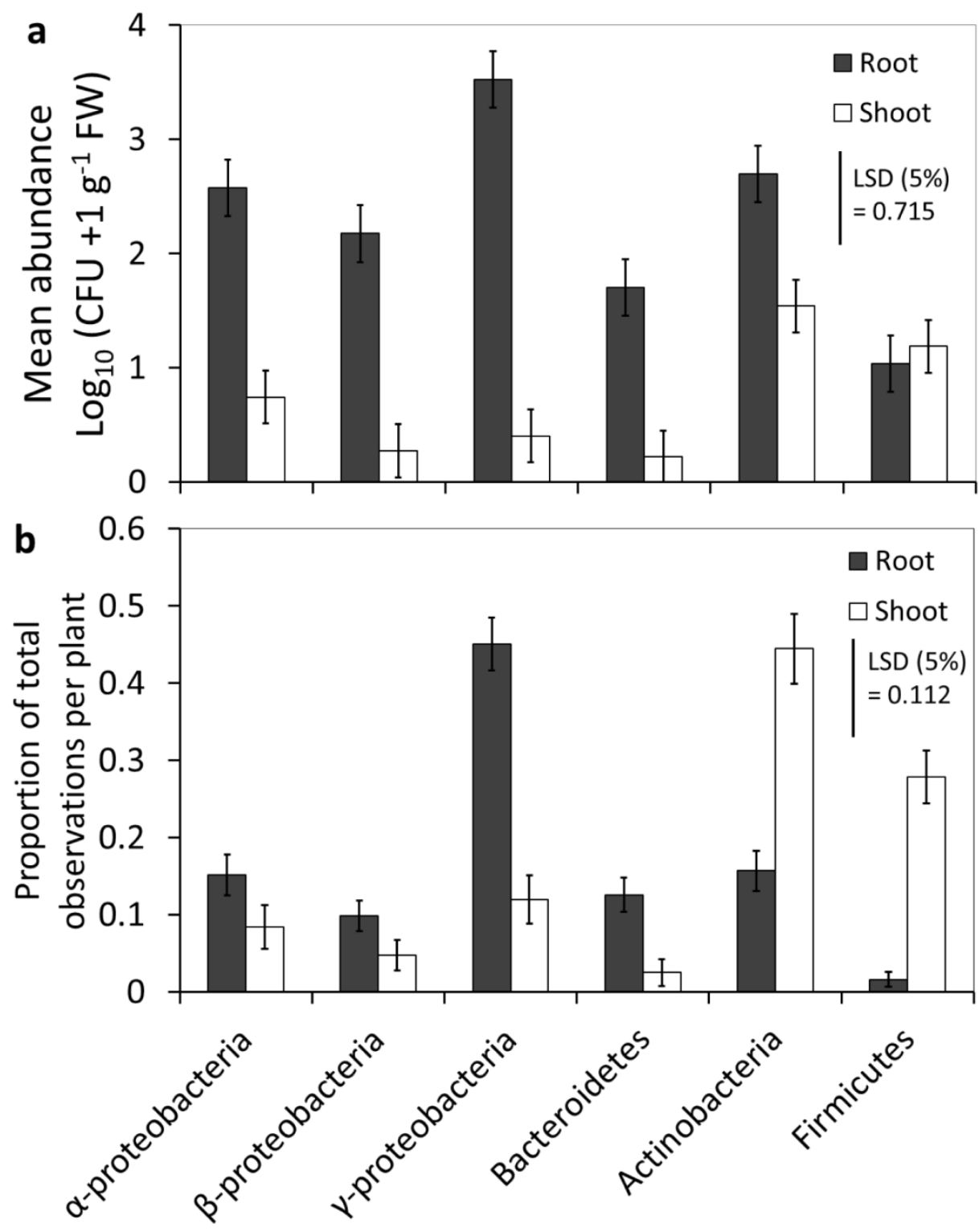
Figure 5

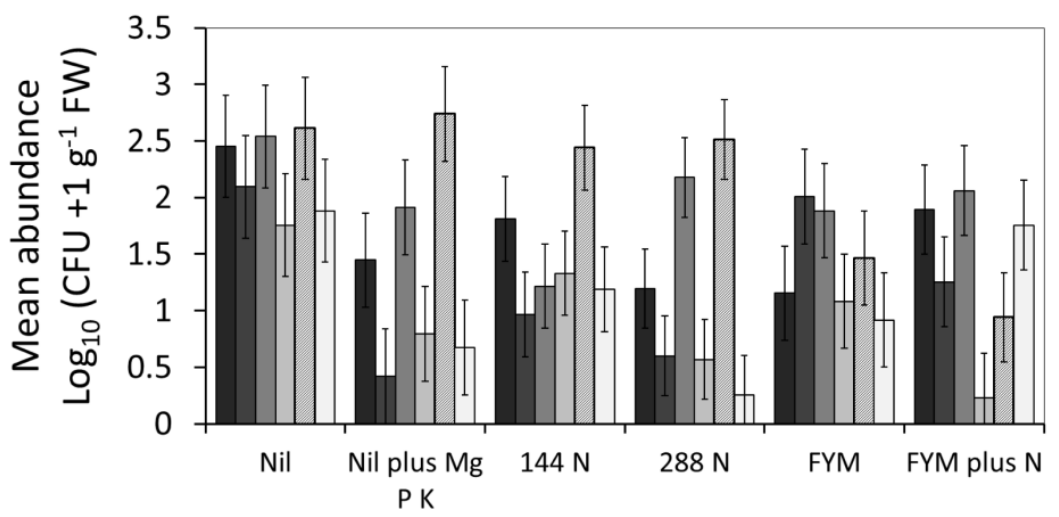

- Alphaproteobacteria

- Betaproteobacteria

$\square$ Gammaproteobacteria

$\square$ Bacteroidetes

$\square$ Actinobacteria

$\square$ Firmicutes 
Figure 6

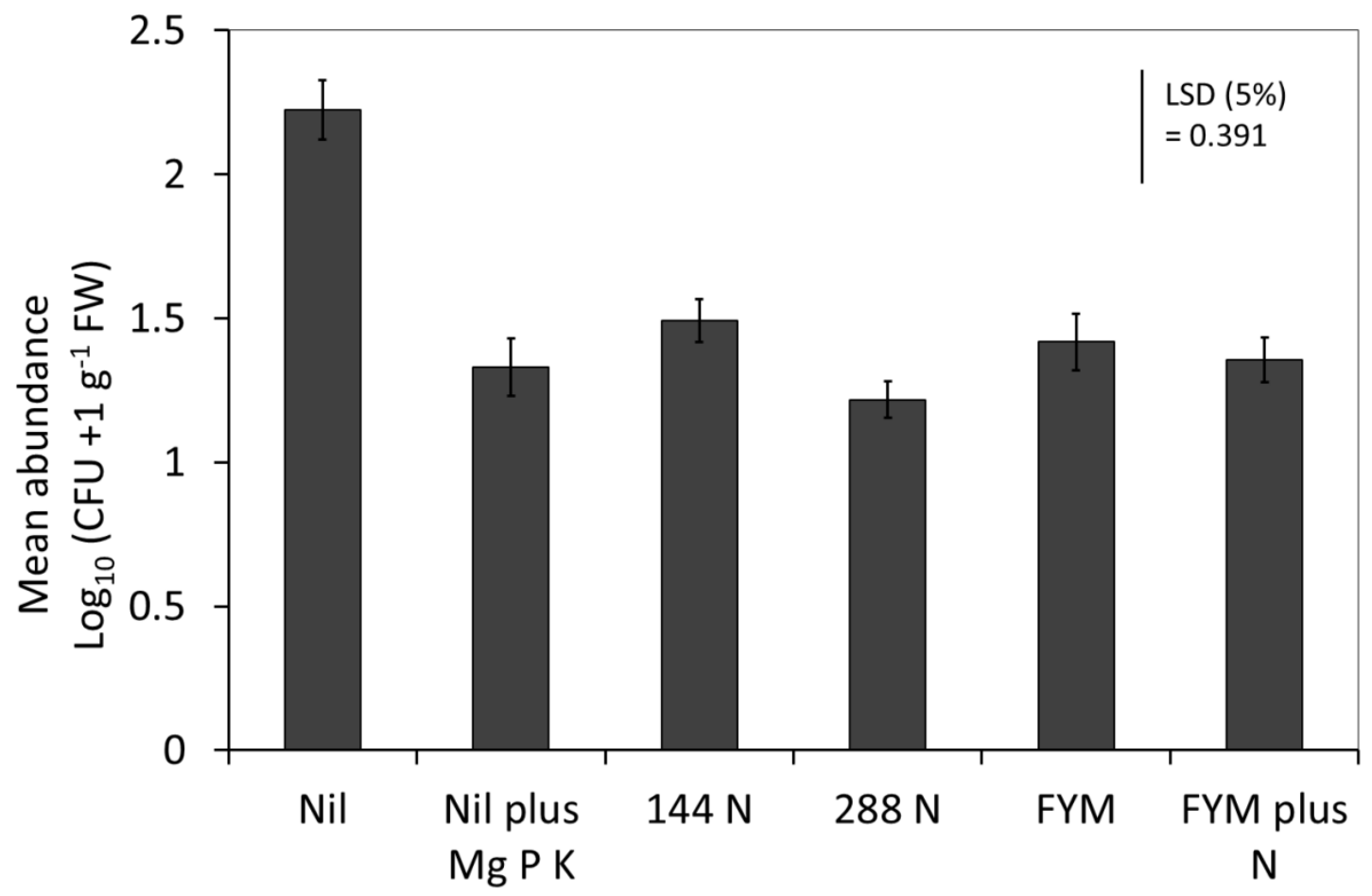


Figure 7

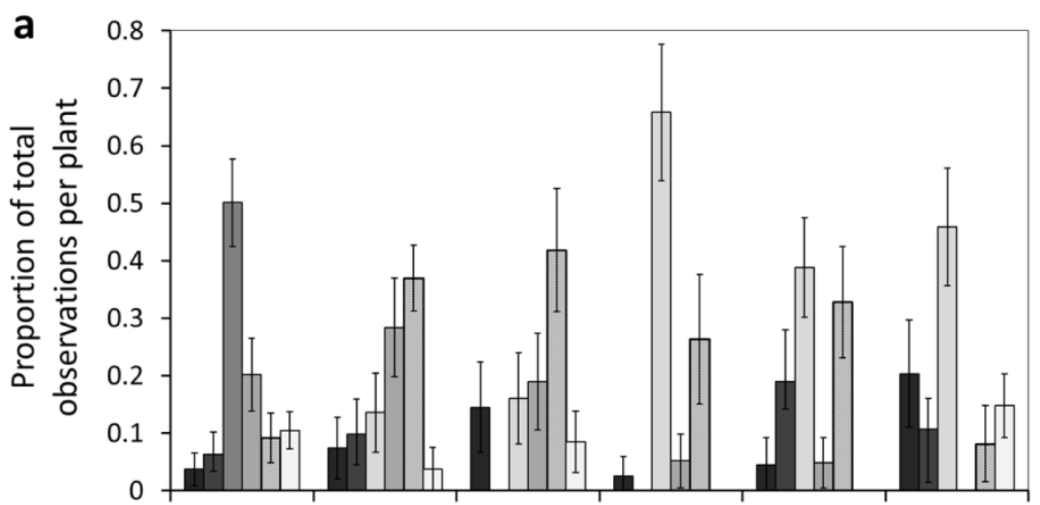

- Alphaproteobacteria

- Betaproteobacteria

$\square$ Gammaproteobacteria

$\square$ Bacteroidetes

Actinobacteria

$\square$ Firmicutes

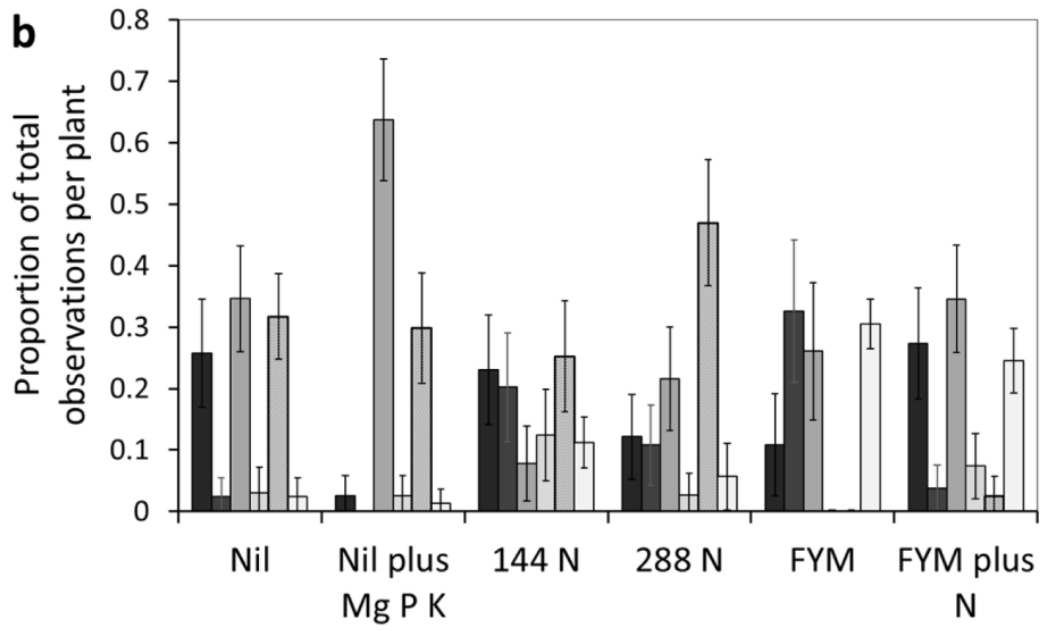


Figure 8
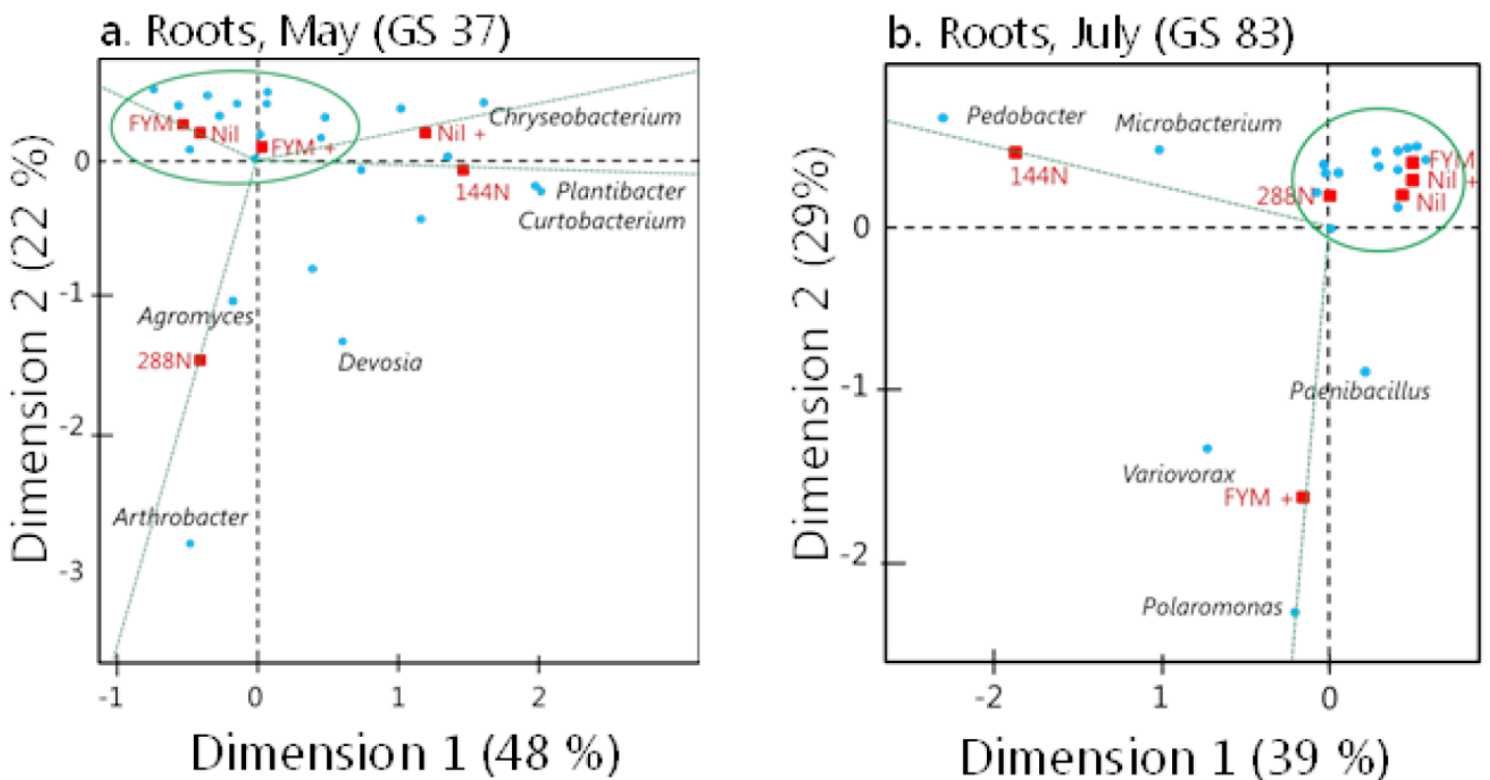

Dimension 1 (39\%)
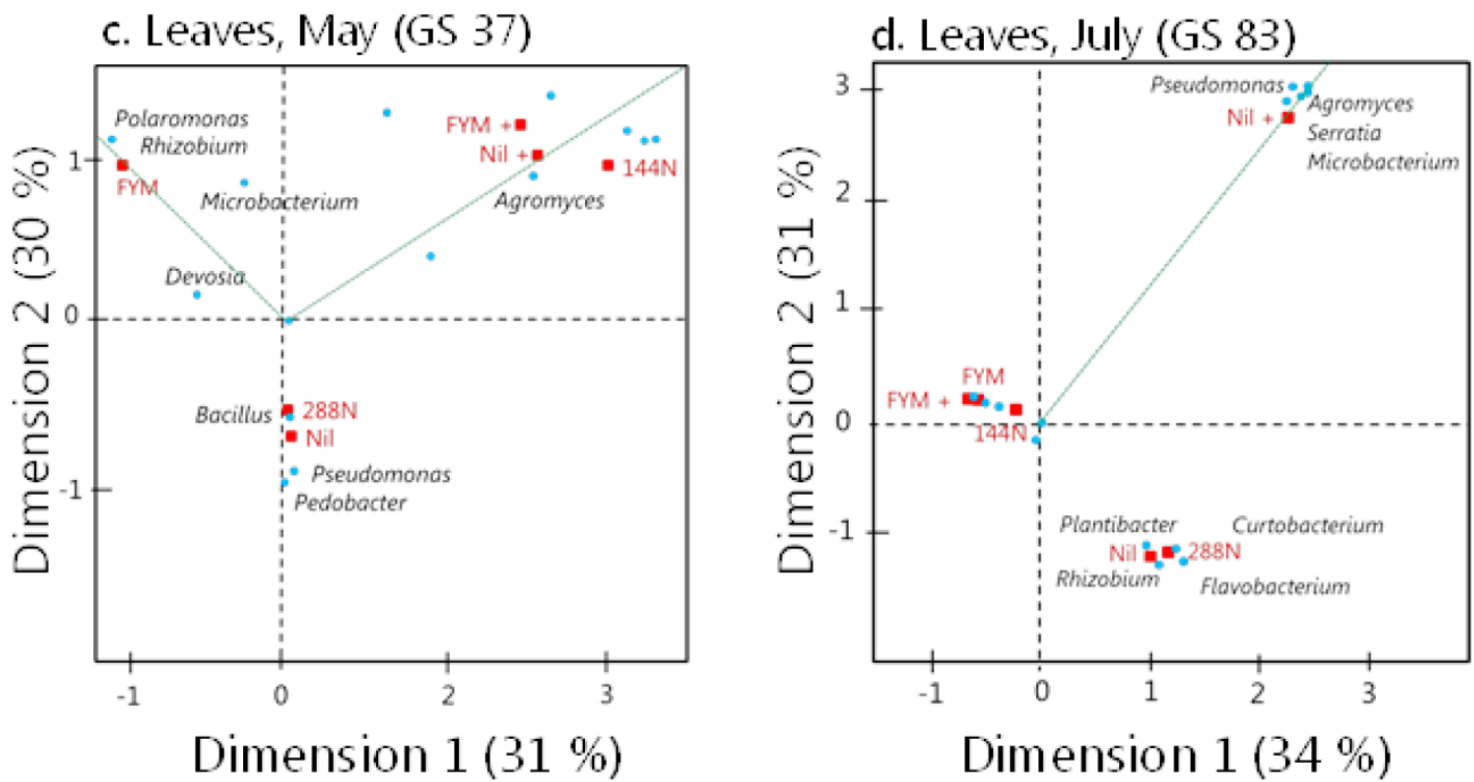
Figure 9

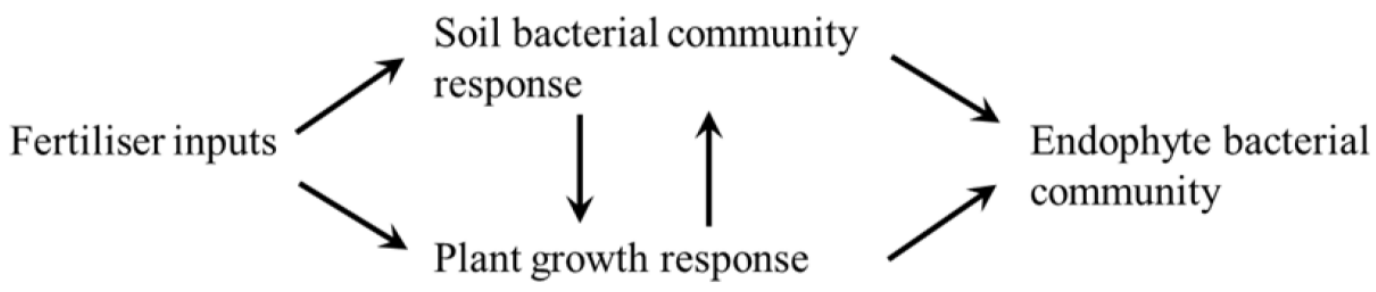

influences 
Fig 1 The Broadbalk long term classical experiment at Rothamsted Research, UK. a) Schematic of treatments. b) Aerial photograph

Fig 2 RFLP profiles for OTUs 1-28. An approximately 1,050 bp region of the 16S rRNA gene was amplified using the primers MF and 1389, then digested in separate reactions with the restriction enzymes, BstU1 (a), Hha1 (b) and Rsa1(c). Restriction fragments were separated on a $3 \%$ agarose gel at $2.5 \mathrm{~V} / \mathrm{cm}$ for 3 hours. 100 bp marker between every 6 samples (M). Gel lanes with no sample are indicated as a Blank (BI) lane.

Fig 3 Rarefaction curves for OTUs at the genus level provided by the RFLP analysis. The black line represents root endophytic samples. The green line represents leaf endophyte samples.

Fig 4 Abundance and relative proportions of phyla in the root and leaf tissues. a) Endophyte abundances $\left.\left(\log _{10}\left(\mathrm{CFU}+1 \mathrm{~g}^{-1} \mathrm{FW}\right)\right) \mathrm{LSD}_{0.05}=0.715 \mathrm{~b}\right)$ Relative proportions of phyla $\mathrm{LSD}_{0.05}$ $=0.112$. The phylum Proteobacteria has been further divided to the subclass level. Standard errors for predicted means are indicated on bars. Mean values calculated from a total of 64 plants.

Fig 5 Abundance of endophytes within each treatment plot. The phylum Proteobacteria has been further divided to the subclass level. Standard errors for predicted means are indicated on bars. Maximum $\mathrm{LSD}_{0.05}=1.714$. Mean values are calculated from minimum of 9 plants per treatment.

Fig 6 Mean abundance of endophytes across all phyla within each treatment plot. Standard errors for predicted means are indicated on bars. Maximum $\operatorname{LSD}_{0.05}=0.380$. Mean values are calculated from minimum of 9 plants per treatment.

Fig 7 Proportion of observations of each phylum within each treatment plot a) May b) July. Standard errors for predicted means are indicated on bars. Mean values are calculated from minimum of 3 plants per treatment. 
Fig 8 Correspondence analysis plots illustrating the associations between soil treatments and endophytic bacterial OTUs. a) Root associated OTUs sampled in May. b) Root associated OTUs sampled in July. c) Leaf associated OTUs sampled in May. d) Leaf associated OTUs sampled in July. For each plot the two dimensions describe more than $60 \%$ of the total inertia. Additional axis to indicate lines of association have been added in green. The clusters of treatments and OTUs with little association have been circled near the origin. Key OTUs are indicated by name.

Fig 9 Schematic of the mechanisms through which fertiliser inputs may influence the structure of the endophytic bacterial community. Fertiliser inputs may directly alter the soil bacterial community and hence alter the available bacterial pool for endophyte entry into roots. Alternatively fertiliser inputs may alter plant root exudates and/or growth thereby altering recruitment of endophytes by the plant growth response. 


\section{Supplementary data}

\section{REML test statistics}

Table 1 REML estimated variance components

\begin{tabular}{lll}
\hline Random term & Component & S.e \\
\hline Replicate_subplot & -0.279 & 0.125 \\
Replicate_subplot.Sample_time & 0.439 & 0.248 \\
\hline
\end{tabular}

Table 2 REML residual variance model

\begin{tabular}{lll}
\hline Term & Estimate & s.e. \\
\hline Residual & 1.719 & 0.173 \\
\hline
\end{tabular}

Table 3 REML mixed effects, sequentially adding terms to fixed model

\begin{tabular}{|c|c|c|c|c|c|}
\hline Fixed term & $\begin{array}{l}\text { Wald } \\
\text { statistic }\end{array}$ & n.d.f. & $\begin{array}{l}\text { F. } \\
\text { statistic }\end{array}$ & d.d.f. & F pr. \\
\hline Sample_time & 1.06 & 1 & 1.06 & 11.7 & 0.325 \\
\hline Treatment & 63.04 & 5 & 12.60 & 4.2 & 0.013 \\
\hline Phylum & 38.04 & 5 & 7.63 & 197.2 & $<0.001$ \\
\hline Tissue & 120.29 & 1 & 120.29 & 204.3 & $<0.001$ \\
\hline Sample_time.Treatment & 3.60 & 5 & 0.72 & 11.7 & 0.622 \\
\hline Sample_time.Phylum & 8.37 & 5 & 1.67 & 197.2 & 0.142 \\
\hline Treatment.Phylum & 40.47 & 25 & 1.62 & 197.2 & 0.038 \\
\hline Sample_time.Tissue & 1.98 & 1 & 1.98 & 203.6 & 0.161 \\
\hline Treatment.Tissue & 7.98 & 5 & 1.60 & 202.4 & 0.163 \\
\hline Phylum.Tissue & 57.73 & 5 & 11.55 & 197.2 & $<0.001$ \\
\hline Sample_time.Treatment.Phylum & 36.94 & 25 & 1.48 & 197.2 & 0.075 \\
\hline Sample_time.Treatment.Tissue & 9.30 & 5 & 1.86 & 199.7 & 0.103 \\
\hline Sample_time.Phylum.Tissue & 8.29 & 5 & 1.66 & 197.2 & 0.146 \\
\hline Treatment.Phylum.Tissue & 33.31 & 25 & 1.33 & 197.2 & 0.143 \\
\hline Sample_time.Treatment.Phylum.Tissue & 33.20 & 25 & 1.33 & 197.2 & 0.146 \\
\hline
\end{tabular}


GLM test statistics

Table 4 GLM test statistics for proportions of phyla using the raw count data

\begin{tabular}{llllll}
\hline Change & d.f. & Deviance & $\begin{array}{l}\text { Mean } \\
\text { deviance }\end{array}$ & $\begin{array}{l}\text { Deviance } \\
\text { ratio }\end{array}$ & $\begin{array}{l}\text { Approximate } \\
\text { F pr. }\end{array}$ \\
\hline Sample_time & 1 & 0.000 & 0.000 & 0.00 & $*$ \\
Treatment & 5 & 0.000 & 0.000 & 0.00 & $*$ \\
Phylum & 5 & 3.28 .193 & 65.639 & 18.95 & $<0.001$ \\
Tissue & 1 & 0.000 & 0.000 & 0.00 & 1.000 \\
Sample_time.Treatment & 5 & 0.000 & 0.000 & 0.00 & $*$ \\
Sample_time.Phylum & 5 & 53.700 & 10.740 & 3.10 & 0.009 \\
Treatment.Phylum & 25 & 307.243 & 12.290 & 3.55 & $<0.001$ \\
Sample_time.Tissue & 1 & 0.000 & 0.000 & 0.00 & $*$ \\
Treatment.Tissue & 5 & 0.000 & 0.000 & 0.00 & $*$ \\
Phylum.Tissue & 5 & 339.460 & 67.892 & 19.61 & $<0.001$ \\
Sample_time.Treatment.Phylum & 25 & 248.683 & 9.947 & 2.87 & $<0.001$ \\
Sample_time.Treatment.Tissue & 5 & 3.257 & 0.651 & 0.19 & 0.967 \\
Sample_time.Phylum.Tissue & 5 & 25.185 & 5.037 & 1.45 & 0.203 \\
Treatment.Phylum.Tissue & 25 & 122.098 & 4.884 & 1.41 & 0.091 \\
Sample_time.Treatment.Phylum.Tissue & 25 & 37.880 & 1.515 & 0.44 & 0.993 \\
\hline
\end{tabular}


